Research article

\title{
DIFFERENTIATION OF ANATOMIC ENTITIES IN THE DOG STIFLE JOINT FOLLOWING S10B PLASTINATION: COMPARATIVE COLORIMETRIC AND RADIOLOGICAL INVESTIGATIONS
}

\author{
BAKICI Caner ${ }^{1 *}$, AKGUN Remzi Orkun ${ }^{1}$, EKIM Okan ${ }^{1}$, INSAL Burcu ${ }^{1}$, KAYA \\ Ufuk $^{2}$, BILGILI Hasan 3 , BUMIN Ali ${ }^{3}$, CAKIR Ahmet ${ }^{1}$ \\ ${ }^{1}$ Department of Anatomy, Faculty of Veterinary Medicine, Ankara University, Ankara, Turkey; \\ ${ }^{2}$ Department of Biostatistics, Faculty of Veterinary Medicine, Ankara University, Ankara, Turkey; \\ ${ }^{3}$ Department of Surgery, Faculty of Veterinary Medicine, Ankara University, Ankara, Turkey
}

(Received 21 April, Accepted 28 October 2019)

\begin{abstract}
The knee joint is not only the most important and complex structure to present during anatomy lectures, but also a significant region for radiologists and orthopedicians. The objectives of this paper are: 1) to evaluate the efficacy of plastinated specimens by measuring colorimetric differentiation and 2) to compare the anatomical structures of the images obtained from computed tomography (CT) and silicone plastination crosssections and perform three-dimensional (3D) reconstructed models of the specimens. A total of 16 knee joints selected from the $10 \%$ formalin fixed/dissected group $(n=6)$, non-fixed/dissected group $(n=6)$ and non-dissected whole knee joint group $(n=4)$ were scanned by $\mathrm{CT}$ and plastinated by using the $\mathrm{S} 10 \mathrm{~B}$ silicone technique. The color changes of the structures were quantitatively determined with the colorimeter device. Plastinated whole knee joints were cut transversally with a band saw and compared with CT images. Finally, 3D reconstruction of the knee joints was performed from CT images with the 3D reconstruction program. There were statistically significant differences between the fixed and non-fixed groups in terms of color changes $(p<0.001)$. The anatomical structures were identified and matched in the cross-sections of plastinates and corresponding CT images. It was observed that plastinated samples were elastic, durable and non-hazardous specimens to use in the veterinary orthopedics and anatomy courses and lectures. It has been found that fixation was useful for the final product morphology. It is thought that the 3D images obtained from this study will support comprehension of the relationships between the bones, muscles, and ligaments.
\end{abstract}

Key words: colorimetric analysis, computed tomography, cross-sectional anatomy, knee, three-dimensional reconstruction.

\section{INTRODUCTION}

The knee joint is an important and complex structure for surgery, radiology, and orthopedic education, as well as for anatomy courses due to the unique formation

\footnotetext{
*Corresponding author: e-mail: vetcanerbakici@gmail.com
} 
and close relation of bones, ligaments, tendons, muscles, vessels, and nerves inside it $[1,2]$. Due to the topographic complexity of the stifle joint, for educational purposes models such as simulators, cross-sectional imaging, computer-assisted 3D modeling, plastination, and surgical or anatomical practices on cadavers are favored. Besides the considerable advantages, these techniques may have some disadvantages [3,4].

Plastinated and 3D models have become the most preferred education materials for educators, especially in the last decade $[3,5,6]$. Cross-sectional or 3D images obtained by magnetic resonance (MR) or CT imaging techniques have frequently been used to diagnose specific diseases, detect pathological alterations, create pre-operative strategies and prevent post-operative complications. In addition to that, these images can be quite convenient to design anatomical and surgical education models $[1,2,7,8]$. To designate the relationship of the anatomical or pathological structures, MR and CT images can also be quite useful. CT provides a distinct identity and prevents superposition among the various tissue types such as osseous structures and soft tissues $[4,9,10]$.

Alternative methods to provide real-like specimens and models in anatomy education have been searched for over a long period of time [3]. Formalin fixed and dissected specimens are known to become deformed after a short time. Besides, a high concentration of formaldehyde in various fixation solutions has serious negative effects on human health. Plastination is a modern anatomical technique that is used to prepare real-like specimens of tissues and organs and is used for anatomy education and courses [3,5]. Plastinated specimens are easy to use, carry or preserve without the need for extra care. Specimens are quite durable, odorless and non-toxic and therefore they are frequently preferred for practical training. In addition to the above advantages, some disadvantages such as a partial shrinkage or alterations in natural color and texture can be observed depending upon the plastination process. Although the prevention of color changes in various plastinated specimens is still an important issue, a satisfactory study focused on colorimetric alterations of plastinated tissues has not been published yet $[6,11,12]$.

The purpose of this study can be summarized in three main captions: 1) to evaluate the quality of plastinated joint specimens to be used for educational purposes by quantitative measurements of the colorimetric changes and morphological alterations, 2) to provide a detailed reference for the anatomical structures in the canine knee by comparing CT images and correlated S10B silicone plastinated cross-sections, 3) to obtain 3D reconstructed digital models that will be created from CT images for anatomy education.

\section{MATERIAL AND METHODS}

Specimens. Knee joints of 8 medium-size dog cadavers $(n=16)$ have been used for this study. Digital radiography (anteroposterior - mediolateral) imaging and classical palpation methods were used to ensure that all cadavers have no orthopedic problems. The ethical consent from the local ethical committee of animal experiments in Ankara University was also obtained (Decision Number: 2017-13-105). 
Computed tomography imaging and $3 D$ reconstruction. A single detector spiral type CT device (General Electric, GE Medical Systems, Milwaukee, WI brand, 2119734-2 model) was used for the imaging process. Lateral pilot images were created for accurate planning. The field of view was selected as from the mid-point of the femur to the middle of the tibia and images at $1 \mathrm{~mm}$ thickness were obtained. The scanning parameters were recorded as follows; $120 \mathrm{kV}, 190 \mathrm{mAs}$, window level $1180 \mathrm{HU}$, window width $2350 \mathrm{HU}$ and $512 \times 512$-pixel matrix. 3D reconstructed digital models of the knee joints were created by using 3D Slicer software (4.9.0 version, GitHub, San Francisco). 3D images were obtained by volume rendering on the indicated window level.

Anatomical comparison of CT images and plastinated cross-sections. Plastinated specimens $(\mathrm{n}=4)$ that had not been dissected, were transversally sliced with a band saw in 1 $\mathrm{cm}$ thick slices and cross-sections were photographed. Related cross-sections and matching CT images were anatomically compared. Anatomic formations such as bones, muscles, ligaments were identified and labeled in CT images and plastinated cross-section images (Figure 1-5).
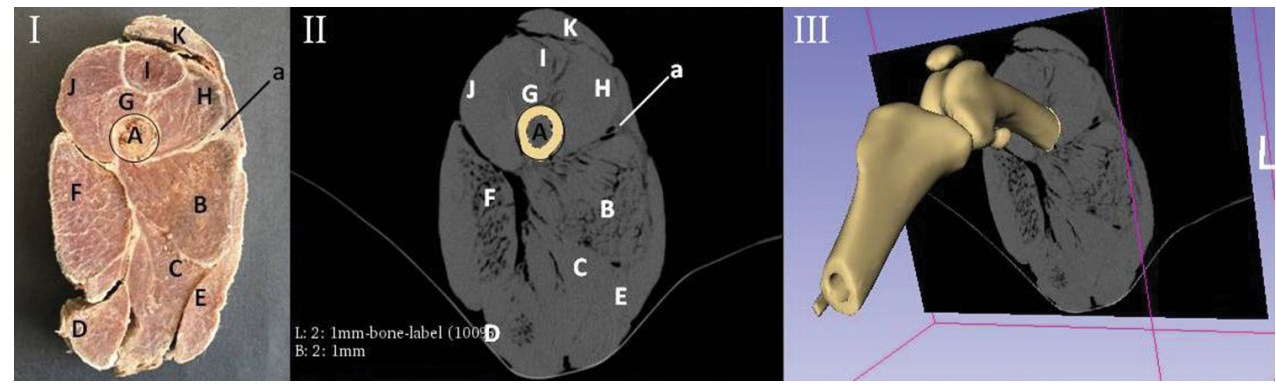

Figure 1. Photograph of a selected transverse plastination section (I), the image of corresponding computed tomography section (II) and 3D reconstruction image of the selected level of the knee joint (III). A-Femur, B-Adductor muscle, C-Semimembranous muscle, D-Semitendinous muscle, E-Gracilis muscle, F-Biceps femoris muscle, G-Intermediate vastus muscle, H-Medial vastus muscle, I-Rectus femoris muscle, J-Lateral vastus muscle, K-Sartorius muscle, a-Femoral artery and vein.
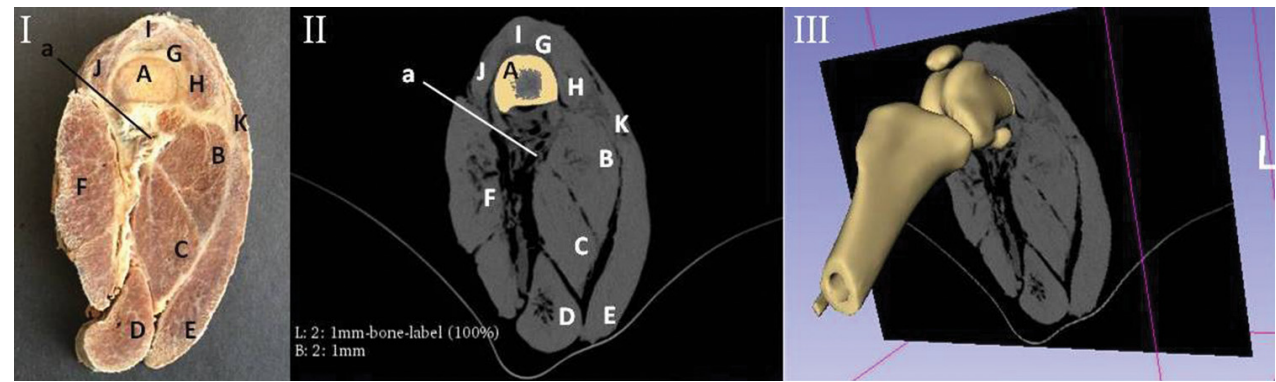

Figure 2. Photograph of selected transverse plastination section (I), the image of corresponding computed tomography section (II) and 3D reconstruction image of the selected level of the knee joint (III). A-Femur, B-Adductor muscle, C-Semimembranous muscle, D-Semitendinous muscle, E-Gracilis muscle, F-Biceps femoris muscle, G-Intermediate vastus muscle, H-Medial vastus muscle, I-Rectus femoris muscle, J-Lateral vastus muscle, K-Sartorius muscle, a-Femoral artery, and vein. 

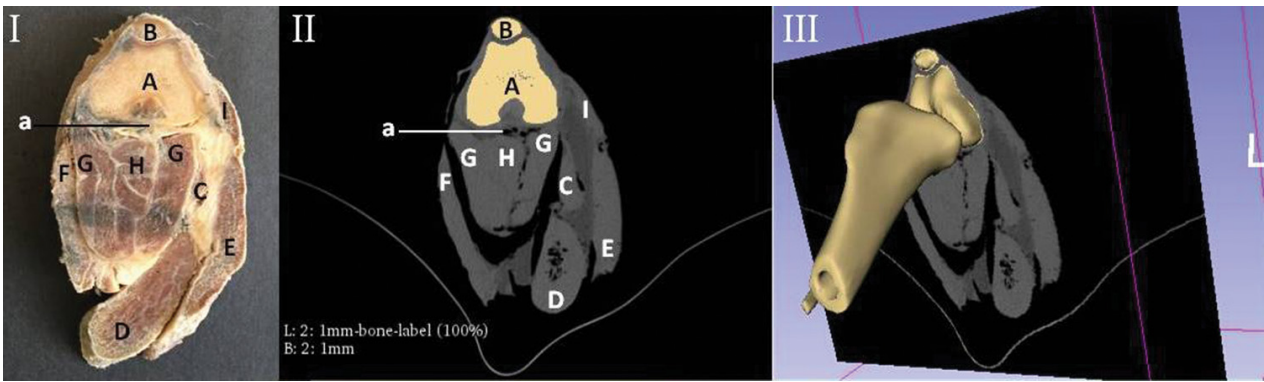

Figure 3. Photograph of selected transverse plastination section (I), the image of corresponding computed tomography section (II) and 3D reconstruction image of the selected level of the knee joint (III). A-Femur, B-Patella, C-Semimembranous muscle, D-Semitendinous muscle, E-Gracilis muscle, F-Biceps femoris muscle, G-Gastrocnemius muscle, H-Superficial digital flexor muscle, I-Sartorius muscle, a-Popliteal artery, and vein.
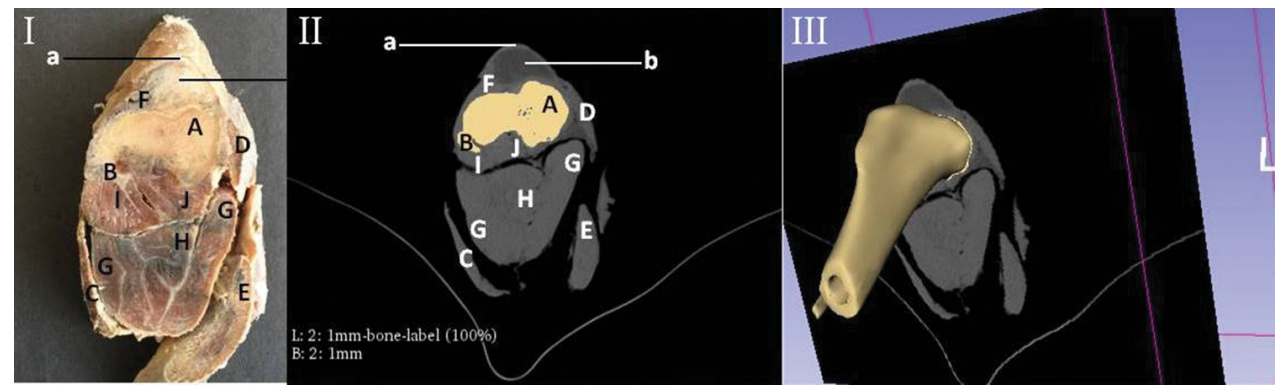

Figure 4. Photograph of selected transverse plastination section (I), the image of corresponding computed tomography section (II) and 3D reconstruction image of the selected level of the knee joint (III). A-Femur, B-Patella, C-Biceps femoris muscle, D-Sartorius muscle, E-Gracilis muscle, F-Long digital extensor muscle, G-Gastrocnemius muscle, H-Superficial digital flexor muscle, I-Lateral digital flexor muscle, a-Patellar ligament, b-Infrapatellar fat pad.

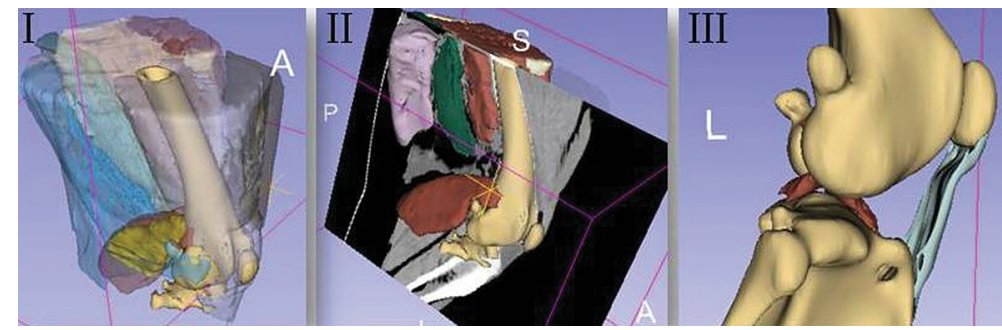

Figure 5. 3D reconstructed views of adductor muscle, semimembranous muscle, semitendinous muscle, gracilis muscle, biceps femoris muscle, intermediate vastus muscle, medial vastus muscle, rectus femoris muscle, lateral vastus muscle, sartorius muscle, gastrocnemius muscle, femur and patella (I-II). 3D reconstructed views of the knee joint with cruciate ligaments and patellar ligament after removing the 3D models of the muscles (III). 
Silicone plastination process. Samples were plastinated in 3 different groups. Specimens of the first group $(n=6)$ were fixed in $10 \%$ formalin solution for 2 weeks and then they were dissected. Specimens of the second group $(n=6)$ were dissected without previous fixation. The whole knee joints $(n=4)$ from the third group were fixed in a $10 \%$ formalin solution for 2 weeks and directly taken to the plastination process.

Formalin fixed groups were kept under running water for 12 hours at room temperature. Afterward, specimens from all groups were placed into pure $(99.5 \%)$ acetone (Birpa Kimya, Ankara) at $-20^{\circ} \mathrm{C}$ for dehydration. Decreasing of acetone purity was measured every 24 hours and the acetone bath was changed when the concentration was fixed at a constant value. The dehydration process was maintained until the acetone concentration was fixed at a value above $95 \%$. The defatting process was skipped due to the scarce presence of adipose tissue in the knee region. All the quantitative parameters (daily concentration change, dehydration period, etc.) were recorded. Low temperature forced impregnation at $-20^{\circ} \mathrm{C}$ was preferred for a stable reaction. Pigmented S10B Reddish polymer (Biodur Products, Heidelberg, Germany) and S3 silicone hardener (Biodur Products, Heidelberg, Germany) were mixed at a 100:1 ratio. At the end of the forced impregnation specimens were kept at $-20^{\circ} \mathrm{C}$ and room temperature, respectively and each keeping period was 24 hours. Final dissections and other retouches were completed before the gas curing-hardening stage. Biodur S6 silicone hardener (Biodur Products, Heidelberg, Germany) was used for the gas curing stage. At the end of the hardening period, plastinates were preserved in a dry, insulated medium.

Colorimetric evaluation. Color measurements of the semitendinosus muscle, semimembranosus muscle, patellar ligament, and femur were performed using a CR 400/410 Colorimeter device (Konica, Minolta, Korea). These measurements were achieved at the International Commission on Illumination (CIE) standards the $\mathrm{L}^{*}$ $a^{*}$ and $b^{*}$ values, where the $L^{*}$ is the brightness of the product on a $0-100$ scale; $a^{*}$ indicates the reddish color changes from green to red and $\mathrm{b}^{*}$ corresponds to the bluish color change from blue to yellow $[13,14]$. Colorimetric parameters were measured at 4 different stages; formalin fixed (Group I) or fresh (Group II), after dehydration, after forced impregnation and at the end of gas curing-hardening stages. An average value was identified for specified structures of all specimens by performing quantitative measurements from the three different points of each structure.

Statistical analysis. Before performing the statistical analysis, data were examined for normality as parametric test assumptions. Descriptive statistics for each variable were calculated and presented as "Mean \pm Standard Error of Mean". To test the differences in each parameter between sampling time in groups, two-way mixed ANOVA was used. When a significant difference was revealed, any significant terms were compared by Simple effect analysis with Bonferroni adjustment. $\mathrm{P}<0.05$ was considered significant in all analyses. SPSS ${ }^{\circledR}$ for Windows 14.1 (License No: 9869264) was used for data analysis. 


\section{RESULTS}

Morphologic and colorimetric results. The plastination protocol with S10B reddish polymer was performed for knee joint specimens. Formalin fixed and non-fixed specimens in two different groups were both well plastinated. The dissected muscles and the articular region itself were quite elastic. However, the morphological features of the structures in the fixed specimens were relatively well preserved when compared with the non-fixed group (Figure 6). Especially osseous tissues in the non-fixed group demonstrated a deviant red color that was determined visually and by colorimetric analyses, as well. A remarkable shrinkage was observed in the muscular tissues of the non-fixed group. Throughout the plastination process, the colorimetric variance for osseous, muscular tissues and ligaments in two different groups was measured. The quantitative differences based on color alterations are presented in Table 1. The anatomic formations were real-like in transversal cross-sections.

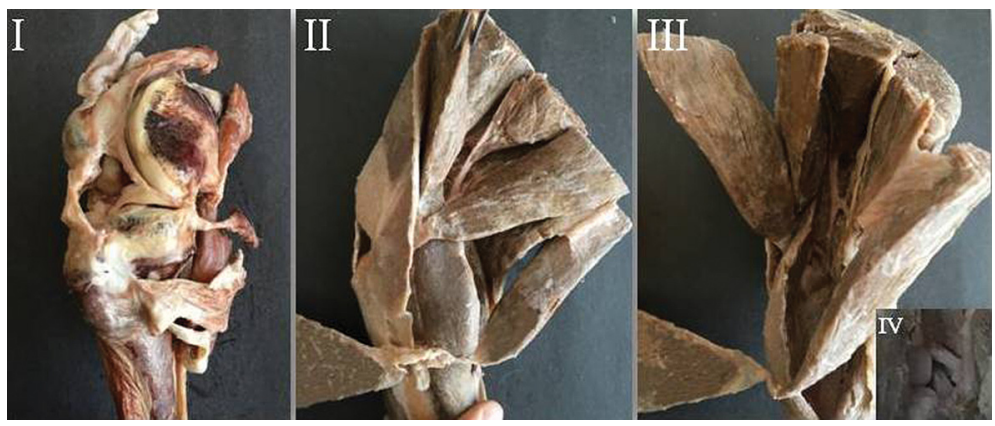

Figure 6. Photograph of non-fixated (I) and fixated plastination specimens from medial (II), caudal (III) and popliteal fossa aspects (IV).

Computed tomography and 3D imaging. Anatomical structures on plastinated crosssections and related CT images were identified and matched on four main transversal images (Figure 1-4). The distribution and borders of the femur, tibia, fibula, patella and fabellae bones were well-defined in CT and plastinated images. The cortical and medullar distinction was also clear. Adductor, semimembranosus, semitendinosus, gracilis, biceps femoris, vastus intermedius, vastus medialis, rectus femoris, vastus lateralis, sartorius, gastrocnemius, popliteus, long digital extensor, lateral digital flexor, and superficial digital flexor muscles could be identified and distinguished among themselves. Meniscofemoral, patellar and cruciate ligaments were observed in similar color intensity. However, collateral ligament could not be easily distinguished from adjacent formations in $\mathrm{CT}$ images. The anatomic formations could easily be identified in cross-sections of plastinates, as well as in corresponding CT images. 3D models obtained from CT images with volume rendering reconstruction techniques were quite convenient for anatomy and surgery courses in terms of re-sectioning or re-imaging of the desired formations in the knee joint (Figure 5). 


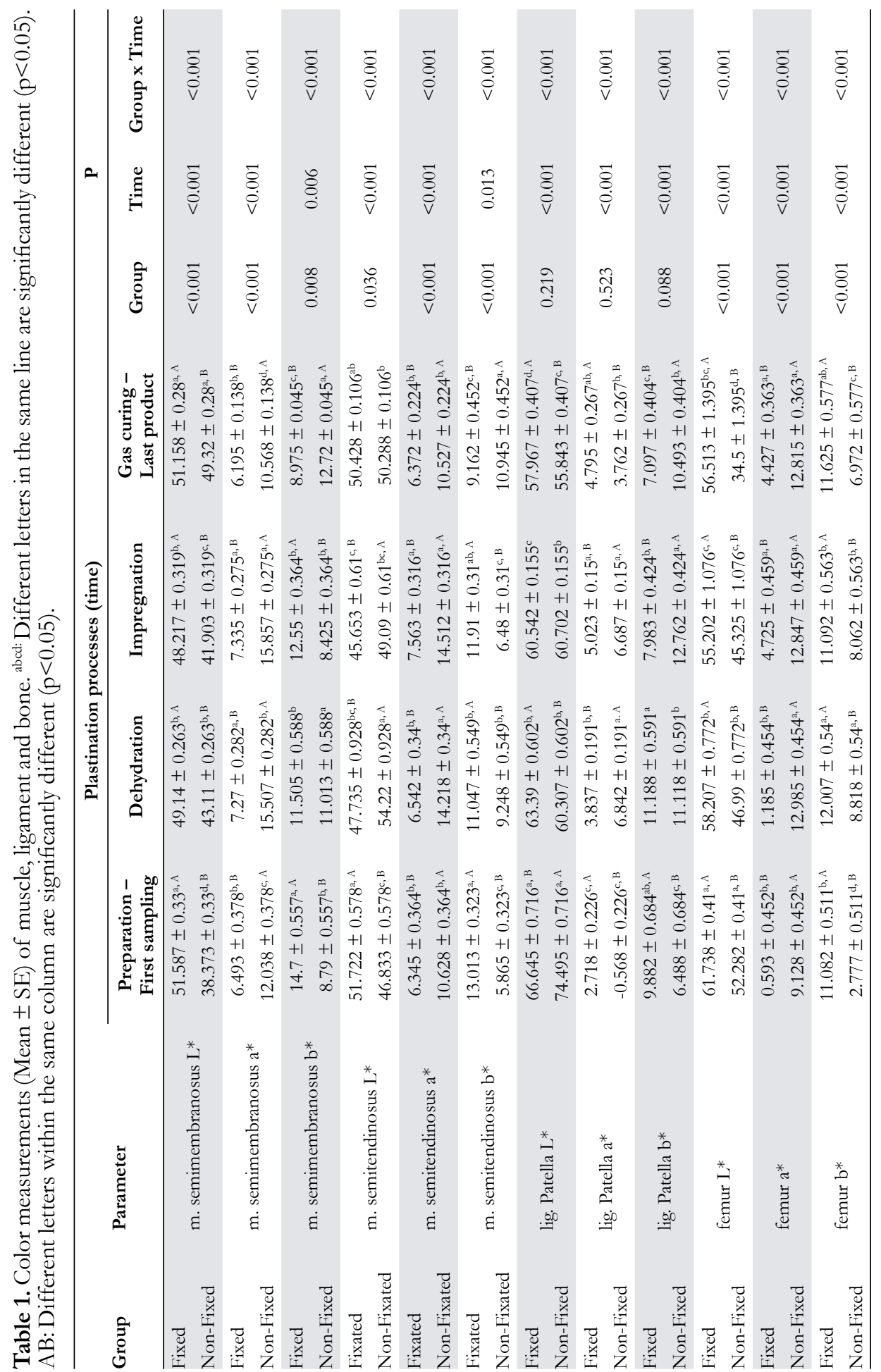




\section{DISCUSSION}

Although radiography and ultrasonography techniques are frequently used in veterinary medicine, CT and MRI techniques have been used in various animals in the recent years. Even though the applied techniques differ in the studies, the anatomical comparison is generally made based on the obtained images $[2,7,9,10,15]$. In this study, it was determined that there is a correlation between anatomical structures on CT and plastinated cross-sectional images. Anatomical nomenclature was easily performed on the cross-sectional images at different levels of the specimens. The bones and surrounding structures are easily distinguished in CT images, but the collateral ligament could not be identified clearly in our study similar to findings obtained by Soler [2]. The distinction between bone and medullary cavity of the femur and tibia was made on cross-section CT images (Figure 1/II - Figure 2/II). Our results are in accordance with the conclusion of Rycke et al. [9], who stated that soft and bone tissue could be displayed together with the correct parameters. In this study, the bone boundaries of the femur, tibia, fibula, patella and sesamoid bones were easily determined, and 3D reconstructions of these bones were also created. Muscles and ligaments around the bones were identified on the CT images, and 3D models of these structures were made at different angles.

There are many educational tools used for surgery, orthopedics and anatomy teaching. Cadavers, plastinated specimens, computer-based 3D images and models prepared with imaging techniques have been foremost among these $[3,5,16]$. The negative effects on the color of the specimens prepared for anatomy education have been caused by the chemicals used in the fixation process and harmful effects of these chemicals on human health has been stated by many researchers $[3,6,16,17]$. In addition to these, another factor that causes a negative effect on the samples is continuous handling [6]. Long-term preservation and use are also very important [18]. Moreover, researchers aimed to find specimens harmless for the human health during the lectures $[6,14]$. There are important contributions to the usage of plastinated specimens as educational material and some studies were stated on these various positive effects on students $[3,16]$. In this study, color differentiation of bones, muscles, and ligaments of the knee joints was calculated quantitatively at each stage of the plastination procedure and evaluated with their natural form. It was observed that the $\mathrm{L}^{*}$ and $\mathrm{b}^{*}$ values of the non-fixed semimembranosus muscle were increased and $a^{*}$ value was decreased from fresh cadaver to the final product. The fixed muscles were preserved the $\mathrm{L}^{*}$ and $\mathrm{a}^{*}$ values. There was a statistically significant difference between fixed and nonfixed semimembranosus muscle with respect to the $\mathrm{L}^{*}, \mathrm{a}^{*}$ and $\mathrm{b}^{*}$ value $(\mathrm{p}<0.001)$. A significant statistical difference was also found between the first values and final values of fixed and non-fixed patellar ligament in terms of $\mathrm{L}^{*}, \mathrm{a}^{*}$ and $\mathrm{b}^{*}$ values $(\mathrm{p}<0.001)$. Fixed bone samples maintained the $b^{*}$ value at every plastination stage. However, the same value for the same tissue has differed in the non-fixed group at every plastination stage. 
In veterinary anatomy education, it is very important to learn the position of the anatomical structures and their relationships [2]. In this study, it was determined that $3 \mathrm{D}$ reconstructed models and the sectional images which have been taken at different planes, can be used for the lectures. It was predicted that the images of the 3D reconstructed models prepared at the desired angles will be good training and working materials. In the published studies, such educational materials have been described as useful visual resources for students [11,16]. Moreover, 3D reconstruction and cross-sectional models are useful in anatomy, radiology, and surgery as well as pathology education to take measurements on specimens, prepare them in the desired positions, determine the pathological structures, negotiate the pre/post-surgical plans and examine the anatomical structures topographically. Besides 3D models, plastinated specimens are also used during anatomy education $[8,11,18]$. Neha [6] stated that samples fixed with formalin at a high concentration had a longer preservation time, but they were not flexible. The features of the plastinated specimens in our study were similar to those obtained by Ekim [19] and Estai [3]. The specimens were elastic, durable, odorless, non-toxic and easy to store so they could be used in veterinary orthopedics and anatomy courses. During the plastination processes, shrinkage of the dimensions of the structures is a known fact [3,18]. In our study, it was observed that the short-term fixation process before the plastination steps was very beneficial to the morphological structure of the final product. It was determined that shrinkage occurred in non-fixed muscles and ligaments.

In conclusion, this research gives detailed anatomical and topographical information about different levels of CT and plastinated images of the canine stifle joint. Although there are a lot of different anatomy education techniques, alternative teaching methods like computer-based learning with 3D reconstruction and 2D sectional images or plastination specimens prepared for different purposes are becoming more important. Therefore, these plastinated specimens are meant to be used in topographic anatomy courses in order to understand the adjacent structures in the stifle joint. This study also provides quantitative data of color differentiation regarding fixation procedures on plastinated specimens.

\section{Authors' contributions}

$\mathrm{BC}$ participated in the study design and conception, study execution, acquisition of photographs and preparation of the manuscript. and ARO and IB contributed to study execution, acquisition of data and photographs, and preparation of the manuscript. $\mathrm{KU}$ contributed to data analysis and interpretation. EO contributed to the language editing and preparation of the manuscript. $\mathrm{BA}, \mathrm{BH}$ and C.A participated in the data interpretation and contributed to revising the article critically for important intellectual content. All authors read and approved the final version of the manuscript. 


\section{Declaration of conflicting interests}

The author(s) declared no potential conflicts of interest with respect to the research, authorship, and/or publication of this article.

\section{REFERENCES}

1. Baird DK, Hathcock JT, Rumph PF, Kincaid SA, Visco DM: Low-field magnetic resonance imaging of the canine stifle joint: normal anatomy. Vet Radiol Ultrasoun 1998, 39:87-97.

2. Soler M, Murciano J, Latorre R, Belda E, Rodríguez MJ, Agut A: Ultrasonographic, computed tomographic and magnetic resonance imaging anatomy of the normal canine stifle joint. Vet J 2007, 174:351-361.

3. Estai M, Bunt S: Best teaching practices in anatomy education: A critical review. Ann Anat 2016, 208:151-157.

4. Samii VF, Dyce J: Computed tomographic arthrography of the normal canine stifle. Vet Radiol Ultrasoun 2004, 45:402-406.

5. Latorre RM, Rodriguez LM: In search of clinical truths: equine and comparative studies of anatomy. Equine Vet J 2007. 39:263-268.

6. Neha, Lalwani S, Dhingra R: Plastinated knee specimens: a novel educational tool. J Clin Diagn Res 2013, 7:1-5.

7. Deruddere KJ, Milne ME, Wilson KM, Snelling SR: Magnetic resonance imaging, computed tomography, and gross anatomy of the canine tarsus. Vet Surg 2014, 43:912-919.

8. Ober CP, Freeman LE: Computed tomographic, magnetic resonance imaging, and crosssectional anatomic features of the manus in cadavers of dogs without forelimb disease. Am J Vet Res 2009, 70:1450-1458.

9. Rycke LM, Gielen IM, Bree H, Simoens PJ: Computed tomography of the elbow joint in clinically normal dogs. Am J Vet Res 2002, 63:1400-1407.

10. Vekens EV, Bergman EHJ, Vanderperren K, Raes EV, Puchalski SM, Bree HJ, Saunders JH: Computed tomographic anatomy of the equine stifle joint. Am J Vet Res 2011, 72:512-521.

11. Sora MC, Genser-Strobl B, Radu J, Lozanoff S: Three-dimensional reconstruction of the ankle by means of ultrathin slice plastination. Clin Anat 2007, 20:196-200.

12. Sora MC, Matusz P: General considerations regarding the thin slice plastination technique. Clin Anat 2010, 23:734-736.

13. Oliveria AC, Balaban MO: Comparison of a colorimeter with a machine vision system in measuring color of gulf of Mexico sturgeon fillets. Appl Eng Agric 2006, 22:583-587.

14. Turan E, Gules O, Kilimci FS, Kara ME, Dilek OG, Sabanci SS, Tatar M: The mixture of liquid foam soap, ethanol and citric acid as a new fixative-preservative solution in veterinary anatomy. Ann Anat 2017, 209:11-17.

15. Shigue DA, Rahal SC, Schimming BC, Santos RR, Vulcano LC, Linardi JL, Teixeira CR: Evaluation of the marsh deer stifle joint by imaging studies and gross anatomy. Anat Histol Embryol 2015, 44:468-474.

16. Latorre RM, Garcia-Sanz MP, Moreno M, Hernández F, Gil F, López O, Ayala MD, Ramírez G, Vázquez JM, Arencibia A, Henry RW: How useful is plastination in learning anatomy. J Vet Med Educ 2007, 34:172-176. 
17. Bakıcı C, Akgun RO, Ekim O, Oto Ç, Özen D, Bilsay M: Is kaiserling solution a convenient fixative for mammalian organ specimens? evaluation of morphometric, colorimetric and volumetric properties. Bulg J Vet Med 2017, 20:62-67.

18. Riederer BM: Plastination and its importance in teaching anatomy. Critical points for longterm preservation of human tissue. J Anat 2014, 224:309-315.

19. Ekim O, Hazıroğlu RM, İnsal B, Bakıc1 C, Akgün RO, Tunalı S: A modified S10B silicone plastination method for preparation and preservation of scaled reptile specimens. Vet $\mathrm{J}$ Ankara Univ 2017, 64:155-160.

\title{
RAZLIKE ANATOMSKIH KARAKTERISTIKA KOLENOG ZGLOBA PASA POSLE S10B PLASTINACIJE: UPOREDNA KOLORIMETRIJSKA I RADIOLOŠKA ISPITIVANJA
}

\author{
BAKICI Caner, AKGUN Remzi Orkun, EKIM Okan, INSAL Burcu, KAYA Ufuk, \\ BILGILI Hasan, BUMIN Ali, CAKIR Ahmet
}

Koleni zglob nije samo jedna od najkompleksnijih anatomskih struktura već predstavlja i značajno područje delovanja radiologa i ortopeda. Cilj rada bio je da se: 1 . Evaluira efikasnost plastinacije merenjem kolorimetrijskih razlika i 2. Da se uporede anatomske strukture snimaka dobijenih kompjuterskom tomografijom (CT) i preseka dobijenih silikonskom plastinacijom uz trodimenzionalnu (3D) rekonstrukcije modela uzoraka. Ukupno je odabrano 16 kolenih zglobova, od kojih je 6 bilo fiksirano u 10\% formalinu, šest je bilo nefiksirano posle disekcije a kod četiri zgloba nije obavljena disekcija niti je tkivo bilo fiksirano u formalinu. Svi su preparati skenirani (CT) uz primenu plastinacije korišćenjem S10B silikon tehnike. Promena boje u strukturama bila je kvantitativno određivana korišćenjem kolorimetra. Ceo koleni zglob nakon plastinacije je transverzalno presečen posle čega je obavljeno upoređivanje sa CT slikom. Konačno, 3D rekonstrukcija kolenih zglobova obavljena je na osnovu CT slika primenom 3D rekontrukcionog programa. Uočene su statistički značajne razlike između grupa fiksiranih i nefiksiranih zglobova u smislu promene boje $(\mathrm{p}<0,001)$. Anatomske strukture preseka plastinacija i odgovarajućih CT slika su identifikovane i upoređivane. Uočeno je da su i uzorci sa plastinacijom bili elastični, trajni i da nisu predstavljali bilo kakvu opasnost pri upotrebi tokom edukacije iz anatomije i veterinarske ortopedije. Isto tako, zapaženo je da je fiksacija bila korisna u smislu očuvanja morfologije krajnjih proizvoda. Smatra se da 3D slike koje se dobijaju na način kako je to opisano u ovoj studiji, mogu značajno da doprinesu poznavanju uzajamnih odnosa kostiju, mišića i ligamenata. 